\title{
HLA-B27, molecular mimicry, and ankylosing spondylitis: popular misconceptions
}

\author{
A F GECZY, ${ }^{1}$ J K PRENDERGAST $,{ }^{1} \mathrm{~J} S \mathrm{SULLIVAN},{ }^{1} \mathrm{~L}$ I UPFOLD, ${ }^{1}$ \\ LE McGUIGAN, ${ }^{1}$ H V BASHIR, ${ }^{1}$ M PRENDERGAST, 1 AND J P EDMONDS ${ }^{2}$
}

From the ${ }^{1}$ NSW Red Cross Blood Transfusion Service, 153 Clarence Street, Sydney, NSW 2000, Australia; and the ${ }^{2}$ Rheumatology Department, The St George Hospital, Kogarah, NSW 2217, Australia

There has been a tendency by several authors during the past few years to interpret all observations of apparent cross reactivity between micro-organisms and self antigens solely in terms of the molecular mimicry hypothesis. According to this hypothesis, foreign invaders (e.g., bacteria and viruses) and self antigens share antigenic determinants, and this sharing results in the failure of the immune system to recognise as foreign certain determinants on the invading organism. ${ }^{12}$ One of the consequences of shared determinants between self and foreign antigens is the production against foreign antigens of antibodies and other effector mechanisms which attack certain target cells bearing self antigens, and thereby initiate an inflammatory reaction. While data consistent with the molecular mimicry hypothesis have been reported be certain groups, ${ }^{3-5}$ it is also clear that molecular mimicry between HLAB27 and microbial antigens does not adequately explain the observations made by our group during the past seven years, nor indeed the notion of general cross reactivity.

In essence our findings suggest that the cells of HLA-B27 positive patients with ankylosing spondylitis $\left(\mathrm{B}_{27}{ }^{+} \mathrm{AS}^{+}\right)$, but not those of HLA-B27 positive normal individuals $\left(\mathrm{B}^{2} 7^{+} \mathrm{AS}^{-}\right)$, carry on their cell surface an antigenic complex which is cross reactive with a wide range of enteric bacteria. ${ }^{67}$ Since this cell surface determinant is not serologically detectable in the ${ }^{51} \mathrm{Cr}$ release assay on the cells of HLA-B27 negative AS patients or of normals, it is reasonable to suppose that HLA-B27 either forms parts of this so called cross reactive complex or is in some way required for its expression. ${ }^{6}$ Sera which

Accepted for publication 29 July 1986.

Correspondence to Dr AF Geczy, Australian Red Cross Society, Blood Transfusion Service, 153 Clarence Street, Sydney, NSW 2000, Australia.

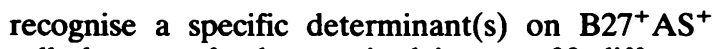
cells have so far been raised in over 30 different rabbits, ${ }^{8}$ but none of these sera has reacted with the cells of $\mathrm{B}^{2} 7^{+} \mathrm{AS}^{-}$individuals, and by implication with HLA-B27 per se. In contrast, the proponents of the molecular mimicry hypothesis suggest that at least partial cross reactivity between HLA-B27 per se and certain micro-organisms, notably klebsiella, is sufficient for the initiation of disease. ${ }^{2}$ Accordingly, AS is produced by organisms which resemble or cross react with HLA-B27. Antibodies to bacteria which cross react with self antigens would activate the complement cascade causing inflammation and ultimately tissue damage, and chronic disease would follow several episodes of inflammation. ${ }^{2}$ At present there is no substantial evidence to support such a pathogenetic sequence.

Whatever the outcome of the debate between our group and the proponents of the molecular mimicry view, we wish to draw attention to several misleading interpretations of our work.

One frequent misconception has been that our findings and those of Ebringer's group both support the idea of direct cross reactivity between klebsiella and HLA-B27, 910 and therefore the so called 'one gene theory'. ${ }^{8}$ We have chosen not to embrace the 'one gene' or the 'two gene' theories as neither satisfactorily explains our observations and these terms are often imprecise and misleading. As stated earlier we prefer to interpret our data in terms of cross reactivity between an HLA-B27 associated structure and certain enteric organisms. This interpretation does not of course rule out either the 'one gene' or 'two gene' theory, but simply adopting one or the other theory does not advance our understanding of the phenomenon of cross reactivity.

Another frequent misunderstanding of our work stems from our observation that certain bacterial 
antigens 'modify' the cells of HLA-B27 positive normal individuals in such a way that these cells behave serologically as the cells of B27 positive AS patients. ${ }^{11}$ Other workers have interpreted these findings as consistent with the idea that HLA-B27 acts as a receptor for certain micro-organisms and have christened it the receptor theory. ${ }^{12-14}$ Although we have conceded that the cells of most healthy HLA-B27 positive individuals appear to bind antigenic determinants from certain bacteria, ${ }^{71}$ it is premature to ascribe this binding to the HLA-B27 molecule per se. It is entirely possible, for example, that the binding of bacterial antigens occurs allosterically and that the 'receptor' is an 'associated structure' rather than the HLA-B27 molecule.

At the heart of our hypothesis is the concept that part of the HLA-B27 associated structure on $\mathrm{B}_{2} 7^{+} \mathrm{AS}^{+}$cells is encoded by a genetic element carried by certain bacteria. ${ }^{15}$ To minimise further misunderstandings of our work it is perhaps pertinent to reiterate the essential elements of our findings: (a) Antisera to certain specific enteric organisms lyse $\mathrm{B}^{2} 7^{+} \mathrm{AS}^{+}$cells in a complement dependent ${ }^{51} \mathrm{Cr}$ release assay, but do not lyse

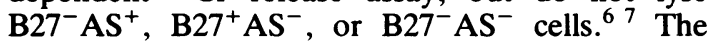
determinant recognised by these antisera is permanently expressed. (b) The culture supernatants of these specific bacteria contain a factor which, when incubated with $\mathrm{B}_{27}^{+} \mathrm{AS}^{-}$cells, renders these cells susceptible to lysis by specific antisera, i.e., they behave serologically as $\mathrm{B}^{2} 7^{+} \mathrm{AS}^{+}$cells. This phenomenon is only transient, however. ${ }^{611}(c)$ The cell culture supernatants obtained from $\mathrm{B} 27^{+} \mathrm{AS}^{+}$ lymphoblastoid cell lines contain a factor which is similar or identical to the factor isolated from these specific bacteria. ${ }^{16}$

Thus on the basis of $(a)$ and $(b)$ it would be reasonable to assume that the same genetic element codes for the factor from certain specific bacteria and that derived from $\mathrm{B} 27^{+} \mathrm{AS}^{+}$cells.

\section{References}

1 Ebringer A. The cross-tolerance hypothesis, HLA-B27 and ankylosing spondylitis. $\mathrm{Br} J$ Rheumatol 1983; 22: 53-66.

2 Ebringer A, Baines M, Ptaszynska T. Spondyloarthritis, uveitis, HLA-B27 and Klebsiella. Immunol Rev 1985; 86: 101-16.

3 Welsh J, Avakian H, Cowling P. et al. Ankylosing spondylitis, HLA-B27 and Klebsiella. I. Cross-reactivity studies with rabbit antisera. Br J Exp Pathol 1980; 61: 85-91.

4 Van Bohemen Ch G, Grumet F C, Zanen H C. Identification of HLA-B27 M1 and -M2 cross-reactive antigens in Klebsiella, Shigella and Yersinia. Immunology 1984; 52: 607-10.

5 Kono D H, Ogasawara M, Effros R B, Park M S, Walford R L. Yu D T Y. Ye-1, a monoclonal antibody that cross-reacts with HLA-B27 lymphoblastoid cell lines and an arthritis causing bacteria. Clin Exp Immunol 1985; 61: 503-8.

6 Geczy A F, Alexander K, Bashir H V, Edmonds J P, Upfold L, Sullivan J. HLA-B27, Klebsiella and ankylosing spondylitis: biological and chemical studies. Immunol Rev 1983; 70: 23-50.

7 Prendergast J K, Sullivan J S, Geczy A, et al. Possible role of enteric organisms in the pathogenesis of ankylosing spondylitis and other seronegative arthropathies. Infect Immun 1983; 41: 935-41.

8 Geczy A F, Upfold L I, Sullivan J S, et al. Rabbit antisera to cross-reactive organisms-where's the problem? Ann Rheum Dis 1986; 45: 85-6.

9 Tiwari J L, Terasaki P I. HLA and disease associations. New York: Springer, 1985: 85-98.

10 Turek P J, Grumet F C, Engleman E G. Molecular variants of the HLA-B27 antigen in healthy individuals and patients with spondyloarthropathies. Immunol Rev 1985; 86: 71-91.

11 Geczy A F, Alexander K, Bashir H V, Edmonds J. A factor $(\$ 2$ in Klebsiella culture filtrates specifically modifies an HLA-B2 associated cell-surface component. Nature 1980; 283: 782-4.

12 Sheldon P. Specific cell-mediated responses to bacterial anti․ gens and clinical correlations in reactive arthritis, Reiter's syndrome and ankylosing spondylitis. Immunol Rev 1985; 86: 5-25.

13 Campa M. Bacterial infections, immunity and reactive arthritides. Clin Exp Rheumatol 1983; 1: 189-93.

14 de Vries R R P, van Rood J J. Immunobiology of HLA class-I and class-II molecules: introduction. Prog Allergy 1985; 36: 1-9.

15 Sullivan J S, Prendergast J K. Geczy A F. The etiology of ankylosing spondylitis: does a plasmid trigger the disease in genetically susceptible individuals? Hum Immunol 1983; 6: 185-7.

16 Orban P, Sullivan J S, Geczy A F, Upfold L I, Coulits N, Bashir H V. A factor shed by lymphoblastoid cell lines of HLA-B27 positive patients with ankylosing spondylitis, specifically modifies the cells of HLA-B27 positive normal individuals. Clin Exp Immunol 1983; 53: 10-16. 